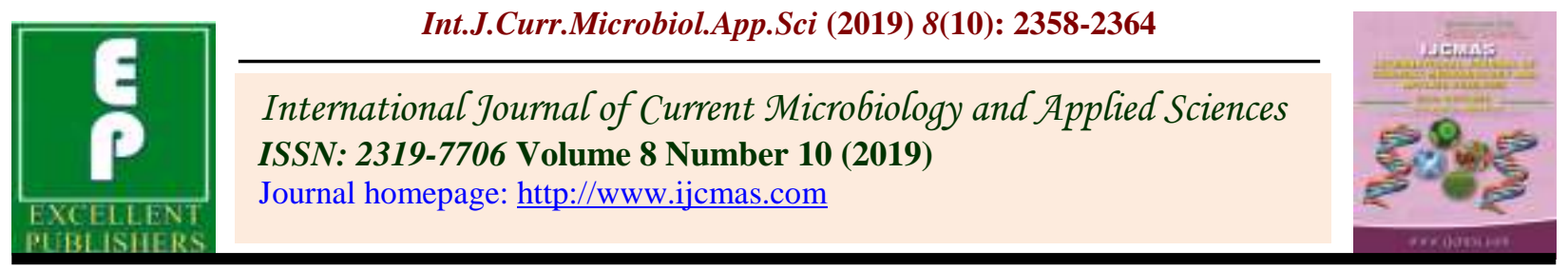

Original Research Article

https://doi.org/10.20546/ijcmas.2019.810.272

\title{
Design Features of Vacuum Seeder for Multiple Crops Sowing in the Trays
}

\author{
T. Prabhakara Rao*, T. Vijay Chowdary, R.V. Sudhakar, \\ K. Kalyani, D. Satyanarayana and A. Daniel
}

Department of Agriculture Engineering, KITS Engineering College, Divili, India

*Corresponding author

\begin{abstract}
A B S T R A C T
Keywords

Vacuum seeder,

Multiple crops,

Labour, Cost

Article Info

Accepted:

17 September 2019

Available Online:

10 October 2019

India uses only 10\% agricultural equipment's as conducted survey in Year 2012. Now a day's India has second rank worldwide in farm output. Agriculture like forestry and fishers accounted for 13.7GDP (Gross Domestic Product) in 2013, about 50\% of the total man power. Precision sowing has been a major thrust of agricultural engineering research for many years; however, most of the research and development work has dealt with seeders for agronomic crops. A seeder should place a seed in an environment in which the seed will reliably germinate and emerge. The individual components were made and assembled the vacuum seeder to meet the demand of farmers to get healthy seedlings in the nurseries with low cost for sowing of seeds in the tray of 50 cells at a time and it will take around $0.5 \mathrm{~min}$ but manual method required around $3.0 \mathrm{~min}$ to sow the seeds in the same tray. We can save $90 \%$ of labour by using vacuum seeder in the nurseries for sowing the seeds in the tray and $70 \%$ of cost can save by using the same machine. The vacuum seeder is having the facility to sow the two trays at a time but two persons are required.
\end{abstract}

\section{Introduction}

The history of agriculture in India dates back to Rigveda, written about 1100BC. In the world the use of agriculture equipment is increasing. India uses only $10 \%$ agricultural equipment's as conducted survey in Year 2012. Now a day's India has second rank worldwide in farm output. Agriculture like forestry and fishers accounted for 13.7GDP (Gross Domestic Product) in 2013, about 50\% of the total man power. The economic contribution of agriculture in India's GDP is continuously decreasing with the country's broad-based economic growth. Still as per 2010 FAO world agriculture record, of wheat and rice, this is the world major food. India has ranked between five largest producers over $80 \%$ of agricultural produce items. All countries used wide range of technology for production of crops including soil cultivation, cutting of crops and the activities of proper processing and marketing. Many different factors influence the kind of agriculture practiced in particular area. It differs from climate, soil fertility and availability for near market place.

India has been bestowed with wide range of climate and physio-geographical conditions and as such is most suitable for growing various kinds of horticultural crops. Its 
horticulture production has increased by 30 per cent in the last five years. This has placed India among the foremost countries in horticulture production, just behind China. During 2012-13, its contribution in the world production of fruits \& vegetables was $12.6 \%$ $\& 14 \%$ respectively. Total production of fruits during 2012-13 was 81.2 million tone's while that of vegetables was 162 million tones whereas the second advance estimates put the production at 84.4 million tone's and 170.2 million tone's respectively for 2013-14. India's an ever-increasing trend of utilizing F1 hybrid seeds has been observed in the vegetable production sector and a major portion of area under vegetable cultivation is now sown with these seeds. Although more expensive than ordinary seeds, these seeds result in higher yields and better quality. In interest of justifying the use of these costly seeds, it is of utmost importance to achieve maximum germination of the seeds into healthy seedlings.

India is the second largest producer of vegetables in the world with an estimated annual production of 99.4 million tons from 6.3 million hectares, which accounts for about $12 \%$ of total world vegetable production (Economic Survey-India 2005-06). A major portion of the area under vegetable cultivation is now sowing with F1 hybrid seeds, which are costly but give higher yields and quality produce. In view of the high cost of such seeds, it is necessary to achieve maximum germination and disease-free seedlings for transplanting in open fields. The raising of seedlings in plug trays (or pro-trays) is one such technology that achieves this requirement. This technology is fast emerging as an agro-enterprise in India since it has obvious advantages for both the grower and the entrepreneur. The plug tray is filled with a soil-less substrate, consisting of coco peat and vermiculite, and one seed is manually placed in each cell. However, placing a single seed in each cell is the most labor-intensive operation.
About eight man-hours are required to sow 100 plug trays for raising 9800 seedlings. This limits the production capacities of most vegetable nurseries due to the non-availability of labour. In the peak season, manual labour hardly meets the requirement for raising vegetable seedlings. Mechanization of the seeding operation of plug trays is therefore necessary to increase the capacity of the rapidly expanding nursery industry in India.

Precision sowing has been a major thrust of agricultural engineering research for many years; however, most of the research and development work has dealt with seeders for agronomic crops. A seeder should place a seed in an environment in which the seed will reliably germinate and emerge. However, no model has been found to describe seeder parameters such as vacuum pressure related with physical properties of seeds. The physical properties of the seeds are the most important factors in determining the optimum vacuum pressure of the precision vacuum seeder.

\section{Materials and Methods}

\section{Design of vacuum operated seed metering mechanism}

We have designed a precision vacuum operated seed metering mechanism by using Auto CAD. For this operation, we prefer a selected vacuum machine shown in figure 1 and labeled the main parts as followed.

1. Vacuum machine

2. Iron frame with ply-wood

3. P.V.C Pipe

4. 3-way ball valve

5. Aluminum frame with ply-wood

Development of vacuum operated seed metering mechanism with required materials

This chapter deals with materials estimation and methodology has followed to develop a 
machine with optimized data to meet the requirement as follows

1. Vacuum Machine

2. PVC pipes

3. 3-way ball valve

4. Plastic pipes

5. Ply-wood stand

6. Seeding trays

7. Aluminum frame with pores ply-wood

\section{Vacuum machine}

A vacuum cleaner also known as a sweeper is a device that uses an air pump (a centrifugal fan in all but some of the very oldest models) to create a partial vacuum to suck up dust and dirt from floors and from other surfaces such as upholstery and draperies.

\section{Technical specifications}

Input voltage $=230 \mathrm{~V}, \mathrm{AC}, 50 \mathrm{HZ}$

Power $($ IEC) $=1200 \mathrm{~W}$

Suction $($ at mean sea level $)=1700 \mathrm{~mm} \quad$ of WC@MSL

Unit weight $=3.6 \mathrm{Kg}$

Dimensions $=330 \mathrm{~mm} \times 230 \mathrm{~mm}$

Revolution per minute $\quad=\quad 1500$

Suction power $\quad=15 \mathrm{KPA}$

\section{PVC pipes}

White plastic pipes commonly used for plumbing and drainage and it become a common replacement for metal piping due to strength, durability, easy installation and low cost have made it one of the most widely used plastics in the world. The 1.5 Inch size pipe was used for making of air flow path in the main frame.

\section{Way ball valve}

Three-way ball valves have 3 ports. They are available in a variety of body materials and with all of the common end connections. We have used as diverter valves where flow a single inlet is diverted to either of the two other ports as the outlet and it was shown in the plate 2.1.

\section{Ply-wood stand}

The base stand was made with $1.5 \mathrm{~cm}$ square rectangular iron rods and plywood of $2.0 \mathrm{~cm}$ thick. It was made with height of $45 \mathrm{~cm}$ and $35 \mathrm{~cm}$ width. The plywood was kept on top of the frame have the size of $35 \mathrm{~cm} \mathrm{x} 40 \mathrm{~cm}$ rectangle in shape and one more same size plywood was kept at the bottom of the frame.

The ball valve set was housed on the top of the frame and vacuum motor was housed on the bottom most plywood. The stand was shown in the plate 2.2 as shown below.

\section{Seeding trays}

The standard size of $27 \mathrm{~cm} \mathrm{x} 52 \mathrm{~cm}$ plastic trays have been using in the nurseries from the beginning. The tray is having 50 cells.

Each cell size of $5 \mathrm{~cm}$ diameter and $4.5 \mathrm{~cm}$ depth and two holes were provided at bottom of the cell to drain out the excess amount of water while growing nursery in the tray. Generally the cells should fill with fertile soil for sowing of seeds. The plastic tray was shown in the plate 2.4 as followed.

\section{Aluminum frame for seed hose pipes}

The frame was developed based on the standard size of seed tray in such a way that the individual seed tube should be co-inside with the centre of the individual cell in the tray.

To meet that requirement, we have taken an aluminum frame of size $37 \mathrm{~cm} \mathrm{x} 65 \mathrm{~cm}$ and made 50 holes to fix the hose pipes to take seeds. 
Fig.1 Design of vacuum operated seed metering mechanism (CAD)

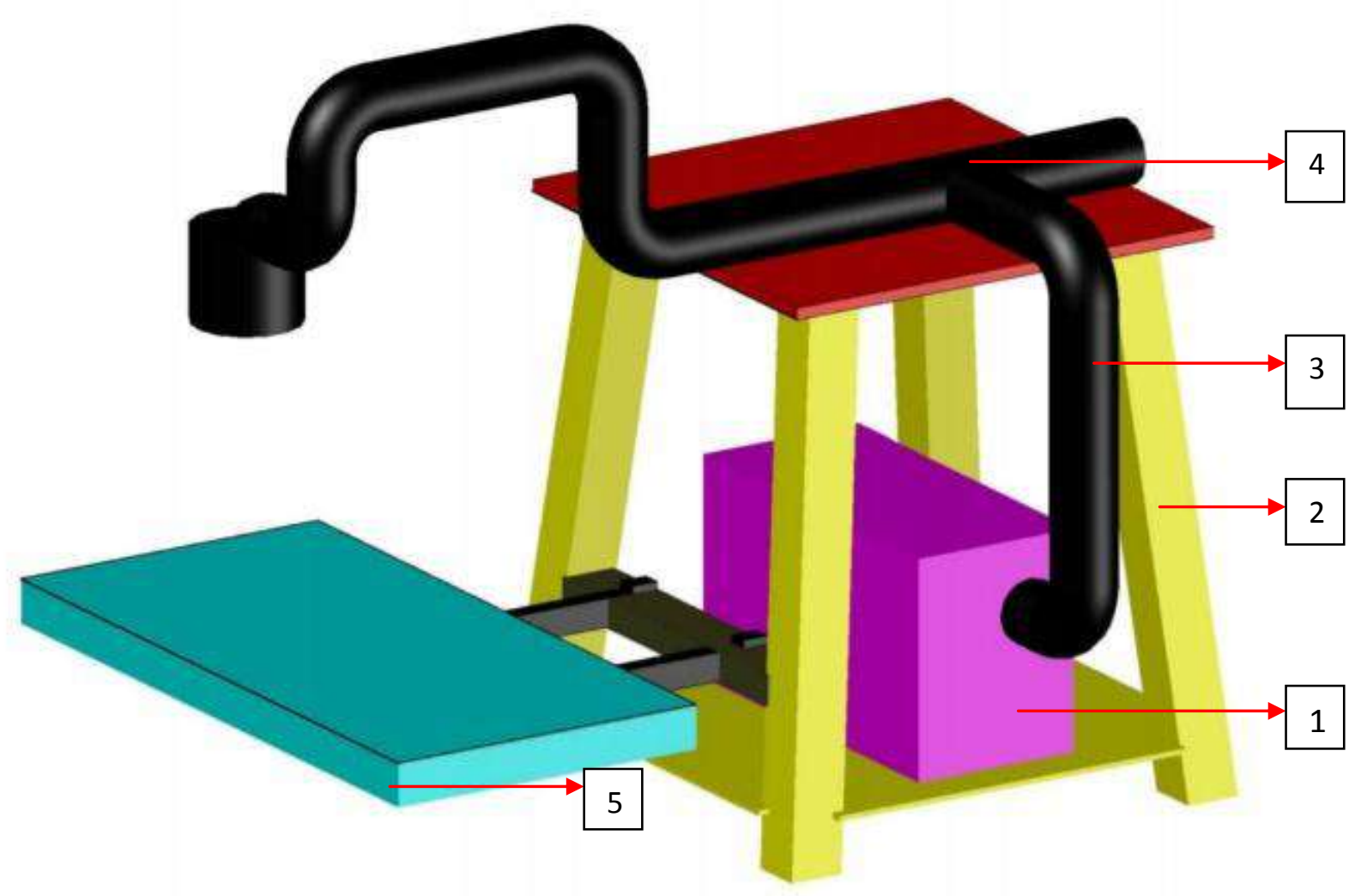

Plate.2.1 3-Way ball valve

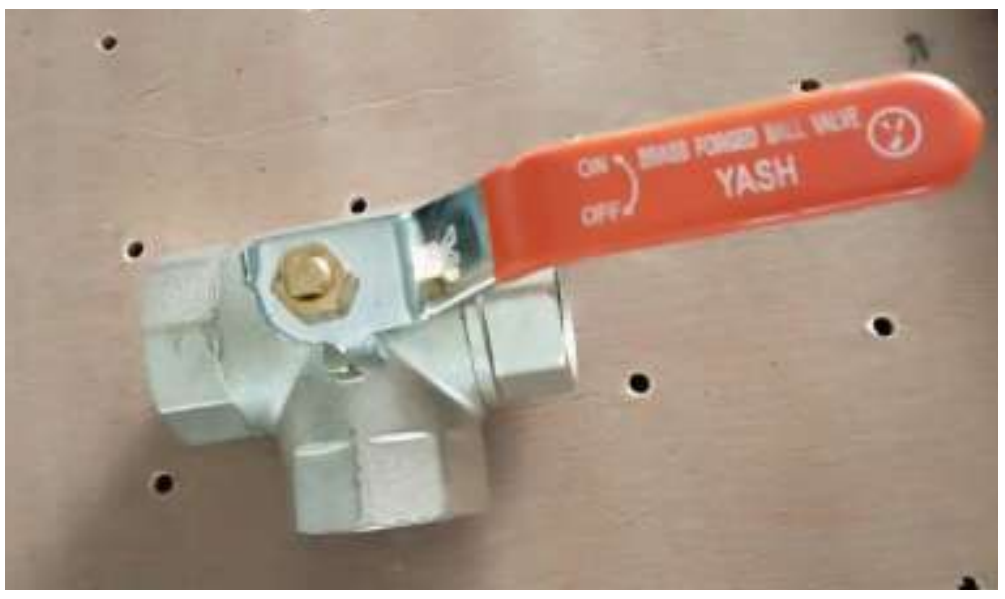


Plate.2.3 Ply-wood stand

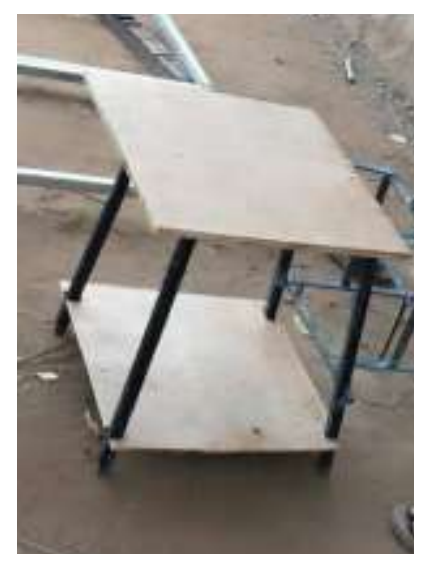

Plate.2.4 Seeding Tray

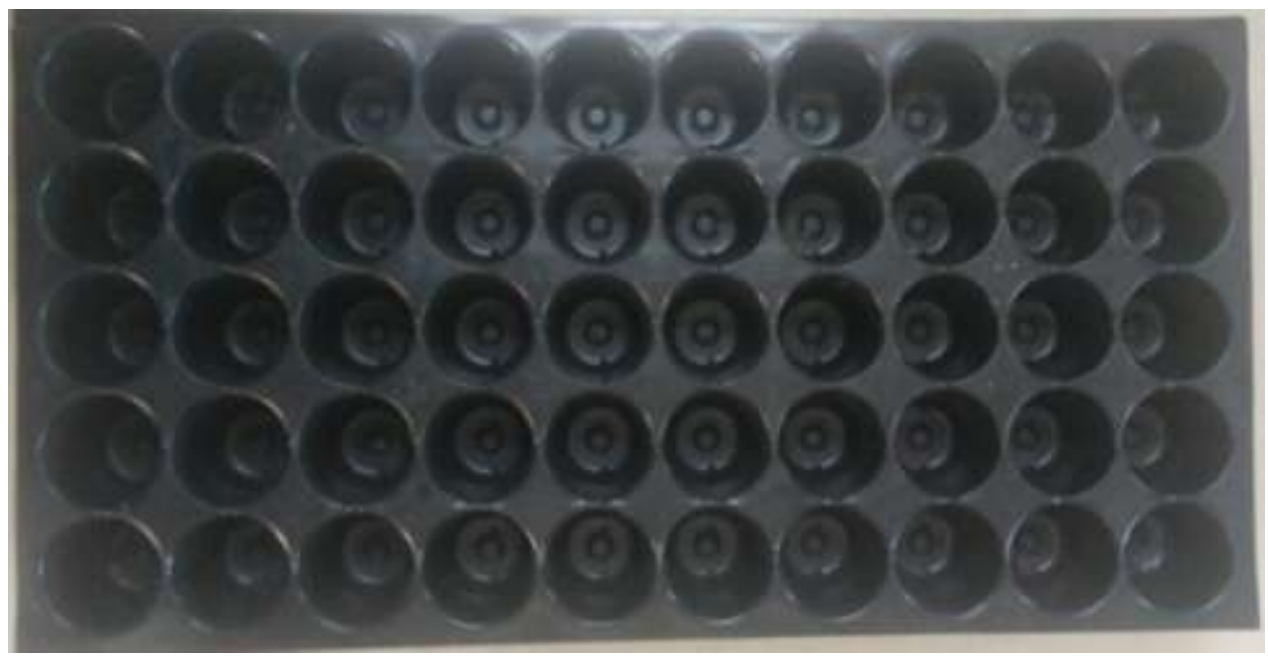

Plate.2.5 Aluminum frame for seed hose pipes

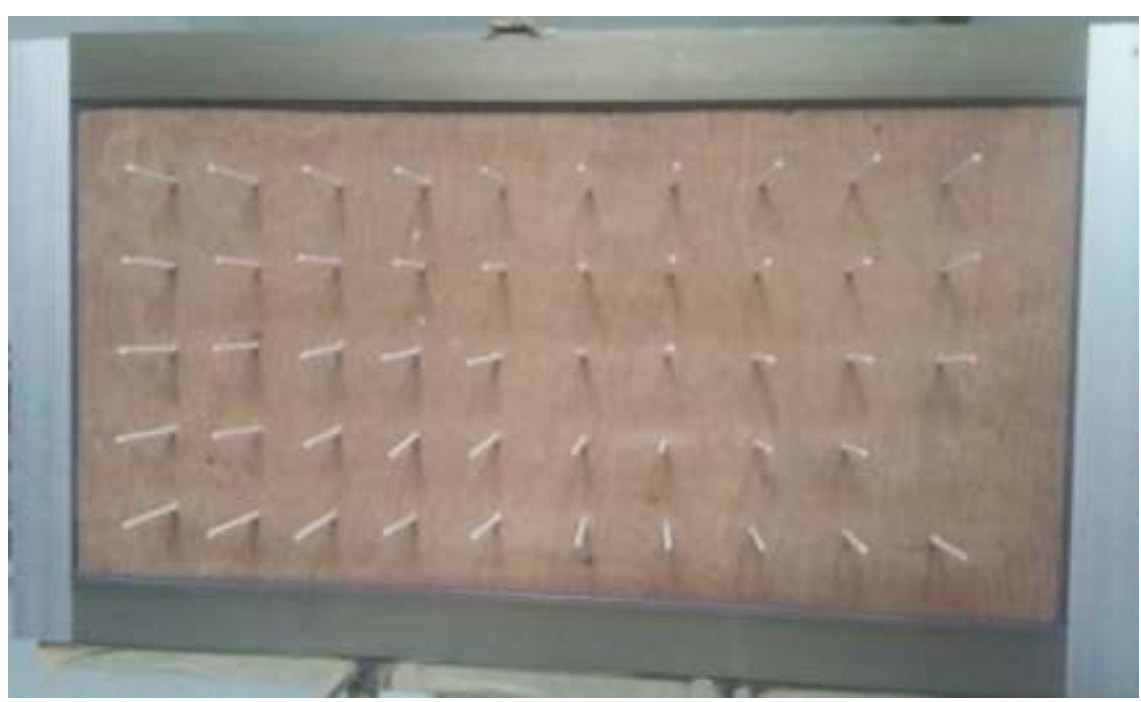


Plate.2.2 Assembled vacuum seeder

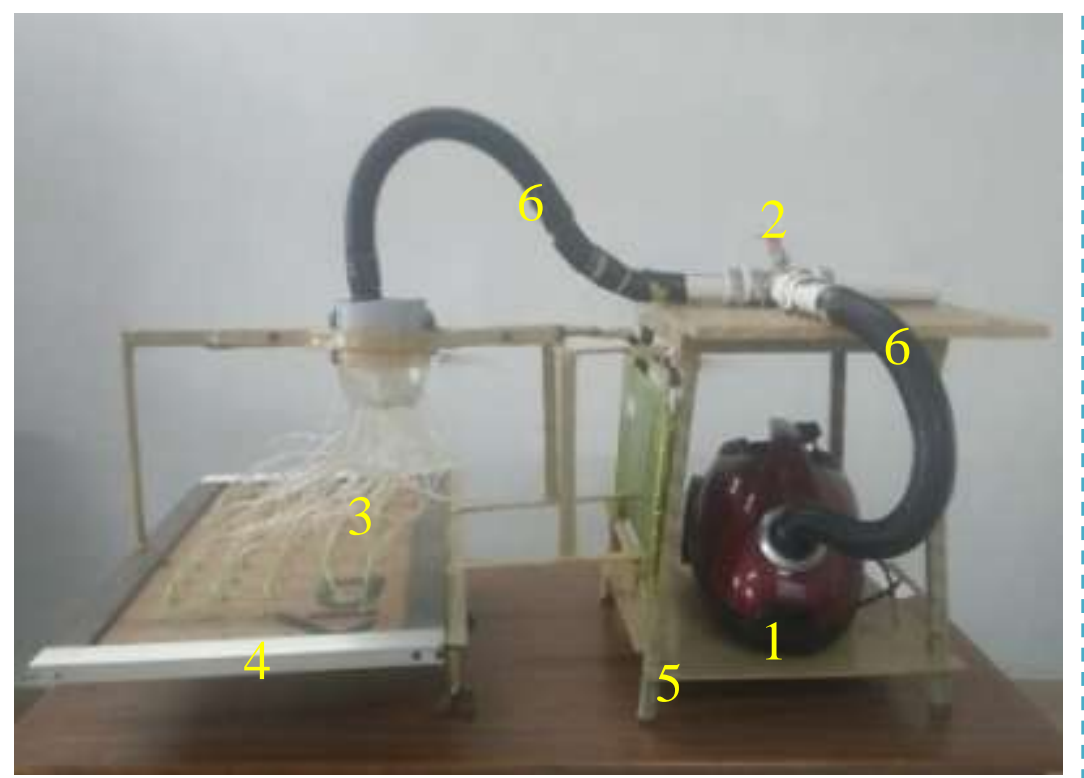

Components of vacuum

seeder

1. Vacuum Machine

2. 3-way ball valve

3. Seed hose pipes

4. Aluminum frame

5. Base stand

6. Air hose pipes

The 50 numbers of hose pipes fixes in the aluminum frame and one end of the pipe fixed to vacuum machine and other end is meant for sucking the seeds to be sown in the tray. The frame was shown $n$ the plate 2.5 as followed.

\section{Assembling of vacuum seeder}

The vacuum machine was connected to the 3 way P.V.C. pipe junction with flexible hose pipe and 3-way ball valve was fixed at the junction point to operate the seeding mechanism. One end of the 50 numbers of hose pipes were fixed towards 3-way junction and other ends were fixed in aluminum frame at marked points. The assembled vacuum seeder was shown in the plate 2.6.

\section{References}

1. Brooks D; Church B (1987). Drill performance assessment; a changed approach. British sugar beet review, 55(4), 50-51

2. Bangjing, J.E. (1996). Pallets-the beginning of material flow. Technology and Strategy of Material Flow, 2: 71-87
3. Baerdemaeker. (2006). Evaluation of seed distribution uniformity of a multi- flight asuger as a grain drill metering device. Biosystems Engineering, 94(4): 535543.

4. C; Lei J H; yu j m; Chang C F (1993). A multi-purpose vacuum seed planter for vegetable crops plantings. Journal of agriculture and forestry, 423(1), 1-18

5. FU, H. G. (1994). Management flow materials (for warehouse management and pallet identification system) Technology of automation, 120:117

6. Giannini G R; Chancellor W J; Garrett R E (1967). Precision planter using vacuum for seed pick up. Transactions of the ASAE, 10(2), 607- 610, 614

7. Gaikwad, B. B. and N.P.S. Sirohi (2008). Design of a low-cost pneumatic seeder for nursery trays. Biosystems Engineering, 99: 322-329.

8. Guarella, P., A. Pellerano, and S. Pascuzzi. (1996). Experimental and theoretical performance of a vacuum seed nozzle for vegetable seeds. Journal of Agricultural Engineering Research, 64(1): 29-36. 
9. Hanacek Wa; (1984), Hu J; Hou J; Mao H (2003). Development and test of magnetic precision seeder for plug seedlings. Transactions of Chinese society of agricultural engineering, 19(6), 122-125

10. Hudspeth E B; Wanjura D F (1970). A planter for precision depth and placement of cotton seed. Transactions of the ASAE, 13(2), 153-155

11. Hofman V (1988) Maximum yields need accurate planting. The sunflower, 14(1), 10-11.

\section{How to cite this article:}

Prabhakara Rao, T., T. Vijay Chowdary, R.V. Sudhakar, K. Kalyani, D. Satyanarayana and Daniel, A. 2019. Design Features of Vacuum Seeder for Multiple Crops Sowing in the Trays. Int.J.Curr.Microbiol.App.Sci. 8(10): 2358-2364. doi: https://doi.org/10.20546/ijcmas.2019.810.272 